\title{
Community of Inquiry and Its Application for Distance Education
}

\author{
Dr. Esther Njiro \\ Senior Lecturer, University of South Africa, College of Education, Department of Abet and Youth Development \\ Preler Street Muckleneuk, P.O, Box 392, UNISA South Africa \\ Email: njiroei@unisa.ac.za
}

\section{Doi:10.5901/jesr.2015.v5n1p123}

\begin{abstract}
Community of Inquiry (COI) is one of the well-defined and described theoretical models of learning in distance education (DE). A lot of research testing the model has been carried out and there is an on-going updating of the model whereby scholars from diverse DE continue to interact continuously about its various dimensions. In this article, the model is described just to update those who do not know what it is all about and some practical ways in which it is applied are demonstrated. Technology has richly transformed the way $D E$ is conceptualised as now there is more interactions and closing of various distances particularly when learning adopts communities of practice. This conceptual paper concludes that COI has greatly enhanced DE by enabling better student retention, better designs of learning materials and higher forms of cognitive, social and teacher presences. COI has also enhanced strategies for designing eLearning.
\end{abstract}

Keywords: Community of Inquiry, Education for all, eLearning

\section{Introduction}

Community of Inquiry (Col) framework is a vibrant process model suitable for defining, labelling and measuring components supportive of development of online learning communities. Swan, Garrison, \& Richardson (2009) say that Col is based on social constructivist progressive understanding by Dewey quoted in Garrison \& Arbaugh, 2007, p. 159) that informs DE and higher education institutions (HEIs). Communities form a vital part of a collaborative learning discourse that is accelerated by the proliferation of learning technologies. A critical community of learners comprises teachers and students performing in a social context for the purposes of clarification and enabling the process of creative authenticating learning. Such communities inspire cognitive, social and teacher presence Col's three critical elements (Garrison \& Anderson, 2003, p. 23). Col has gained prominence since inception because extensive research using the model has been done. This essay reviews the three Col principles with an intention of clarifying how the model has inspired student retention and the way it is applied in various learning contexts in distance education (DE).

\section{What is Community of Inquiry?}

Social, cognitive and teaching presences are the principle terms in COI model and they are well summed up by Swan when she states:

\footnotetext{
... "The Col framework represents the online learning experience as a function of the relationship between three presences: social presence, teaching presence, and cognitive presence...The Col framework suggests that online learning is located at the intersection of these three presences; that is, all three presences are necessary for learning to take place in in an educational context." (Swan, 2010, p. 123).
}

All these work best where information communication technologies (ICTS) are available. Learning occurs at the nexus of the overlap of these three presences as shown in the well-known Col figure. Setting a learning environment that supports discourse and choosing content of what teachers and teaching institutions do in forming the intersection of teacher, cognitive and social presence (Swan, Garrison \& Richardson, 2009). Learning occurs at the nexus of the overlap of these three presences as shown in figure 1 below: 
Figure 1: Community of Inquiry (COI)

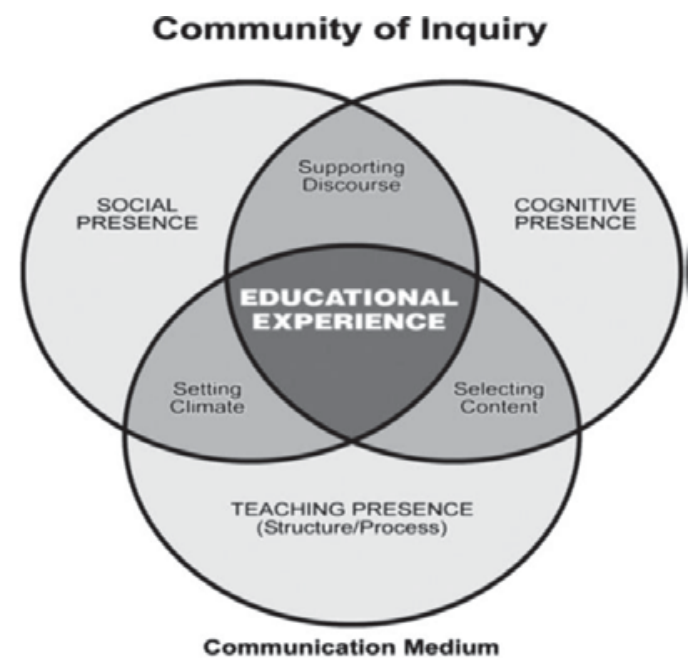

Table 1. Categories constituting the criteria for inclusion in the three Col presences (Garrison \& Arbaugh 2007, p. 158).

\begin{tabular}{|l|l|l|}
\hline Elements & Categories & Indicators \\
\hline Social presence & $\begin{array}{l}\text { Open communication group cohesion and effective } \\
\text { expression }\end{array}$ & $\begin{array}{l}\text { Risk-free expression, encourage collaboration, } \\
\text { emotions }\end{array}$ \\
\hline Cognitive presence & Triggering event, exploration, integration and resolution & $\begin{array}{l}\text { Sense of puzzlement, information exchange, } \\
\text { connecting ideas } \\
\text { apply new ideas }\end{array}$ \\
\hline Teaching presence & $\begin{array}{l}\text { Design and organisation, facilitating discourse, direct } \\
\text { instruction }\end{array}$ & $\begin{array}{l}\text { Setting curriculum and methods } \\
\text { Sharing personal meaning } \\
\text { Focusing discussion }\end{array}$ \\
\hline
\end{tabular}

Projection of personal characteristics and personalities through visible collaborative activities by students leads to active engagement and success in education where COI is working well (Garrison \& Arbaugh, 2007, p. 157). Students conceive, express ideas and are visible in collaborative groups in communication that leads to engaged expressive learners. These authors add that in social presence, humour, anecdotes and amusements signal a stronger sense of community by all participants making social presence not only a criteria for learning and facilitating affective learning. Collaboration increases a sense of common purpose, security to open up and social emotional bonding between those in a Col (Swan \& Shih 2005).

Cognitive presence describes how learners comprehend and are able to construct and approve meaning in a sustained dialogue (Garrison et al., 2000, p.7). Purposive deliberate thinking is critical in cognitive presence with learning being started by a triggering event or a puzzle. Then students start exploring in search of answers to the puzzle by connecting analyzing and integrating ideas and information (Garrison \& Arbaugh, 2007). Where the Col is working well, cognitive presence represents a higher order of knowledge acquisition and application. In well-designed learning materials learners are encouraged to engage in critical and creative thinking.

Teaching presence is described as directing both cognitive and social presence as content is designed in a way that arouses interest leading to realization of personal meaningful and worthy while educational outcomes (Garrison and Arbaugh 2007, p. 163). Teachers should design the curriculum, teaching programs and set up ground rules as facilitators of a shared activity between teachers and students that generates new ideas (Morgan, 2011). To maintain a strong presence as teachers in higher education institutions teacher must direct social and cognitive actions in a learning process with intended achievement of learning outcomes where all three presences of Col are found.

\section{Applied Col Theoretical Framework to Distance Learning}

This section of the paper discusses how Col framework one of the current DE pedagogies on online learning have been 
applied in empowering adult educators in South Africa. To meet the vast numbers of illiterate people in South Africa effective teacher presence training is required. Education for all (EFA) called for opening education opportunities to all regardless of their ethnicity race and other socio economic aspects of diversity so everybody adapts and optimise their abilities in the highly competitive modern world of rapid technology and information generation (UNESCO, 2004).

Adult educators have to cater for diversity of learners young and old, with various levels of literacy, poverty, unemployment and disabilities caused by the apartheid denial of education opportunities to Africans (Department of Education 2003, p. 24). Adult educators are not just facilitators of learning but they are expected to be capacity builders, youth counsellors and implementers of Adult education programs. They have to know how to access health care facilities particularly for the large numbers infected by HIVIAIDS and encourage learners with low self-esteem after suffering years of abuse and exploitation not knowing how to read and write. Disabled learners with all sorts of malfunctions are to be included in adult education classes and large numbers are also a challenging situation.

To meet these challenges distance education institutions have to transform the training of adult educators so they unlearn their face to face ways of teaching that they learned from conventional institutions by learning how to implement learning technologies (Braimoh, (2008). A number of technology-mediated learning for adult educators including Technology Pedagogical Content Knowledge (TPDK) a tutoring and presentation mentioned by Shea and Bidjerano, (2008) are in place. Authors of TPCK, Mishra and Koehler (2006) assessed historical review that differentiates teacher knowledge of learning and teaching discipline and found that it was a constraint to improving instructions. Other modalities of learning in place for teaching adult educators are symbolism, fore telling, self- regulated and self -reflective modalities of lifelong learning (Braimoh, (2008).

Symbolism is about the process of abstracting experiences to form guiding models of learning through use of technology to stimulate value driven collaborative studies. Enabling learners make use of abstract experiences is a wellknown concept in Africa where story telling is part of cultural milieu. Forethought is the educator's capacity to appreciate their self-worth by a deliberate cognitive capacity to judge their capabilities and planning for future events leading to effective learning and therapeutic benefits.

Collaborative relationships in which learner discussions include identification and division of tasks, time management and goals setting to complete group projects successfully have self-regulated individuals. Self-regulation of learners on collaborative online activities motivated behaviour that has both cognition (knowledge to build upon) and metacognition (ability to monitor learning strategies (Braimoh, 2008, p. 236). Metacognition is thinking about thinking an important aspect of human intelligence needing further research particularly on text-based on-line learning (Akyol \& Garrison (2011). Self-selected reading, search of information from Internet and sharing are indicators of self-directed learning exhibiting higher levels of cognitive presence in working Col framework (Shea \& Bidjerano (2010). These authors have also discussed self-reflective and self-efficacy as important aspects of cognitive presence leading that leads to ability to execute a course of action in a specific domain.

Col framework as one of the current DE pedagogies on online learning is premised on a concept that no single medium of learning or of technology generation is enough to support education. Berge and Huang, (2004) have observed a similar view with regard to student retention in DE. Student retention and completion of a learning program should not only be measured by graduations and passing of examinations but also by active student participation and persistence throughout as shown in Col presences Various social forces that pressurize students to withdraw from a learning program in HEls should be identified and dealt with before commencing the learning processes. Institutional organizational characteristics and processes, economic and psychological perspectives also lead to student withdrawal. The complexity of reasons why students are not retained require continuous research as they keep changing,

Anderson and Dron (2011, p. 91) have concluded that "as new affordances open out, it becomes possible to explore and capitalize on different aspects of the learning process." Col's emphasis on constructing and sustaining cognitive, social and teaching presence is useful in selecting what may be referred to as effective DE pedagogies and learning environments. All participants in a Col should be conversant with the academic objectives to be able to establish and sustain all the phases of inquiry and raise the levels of discourse (Garrison, Anderson and Archer, 2000). The distinction between facilitation and direction should be clear from a design perspective as teachers embrace the dual role of both moderating and shaping the direction of the academic discourse as depicted in figure 2 below. 
Figure 2. Towards a strategy for e-learning (Brown, 2002 quoted in Smith and Zenios 2004, p.11).

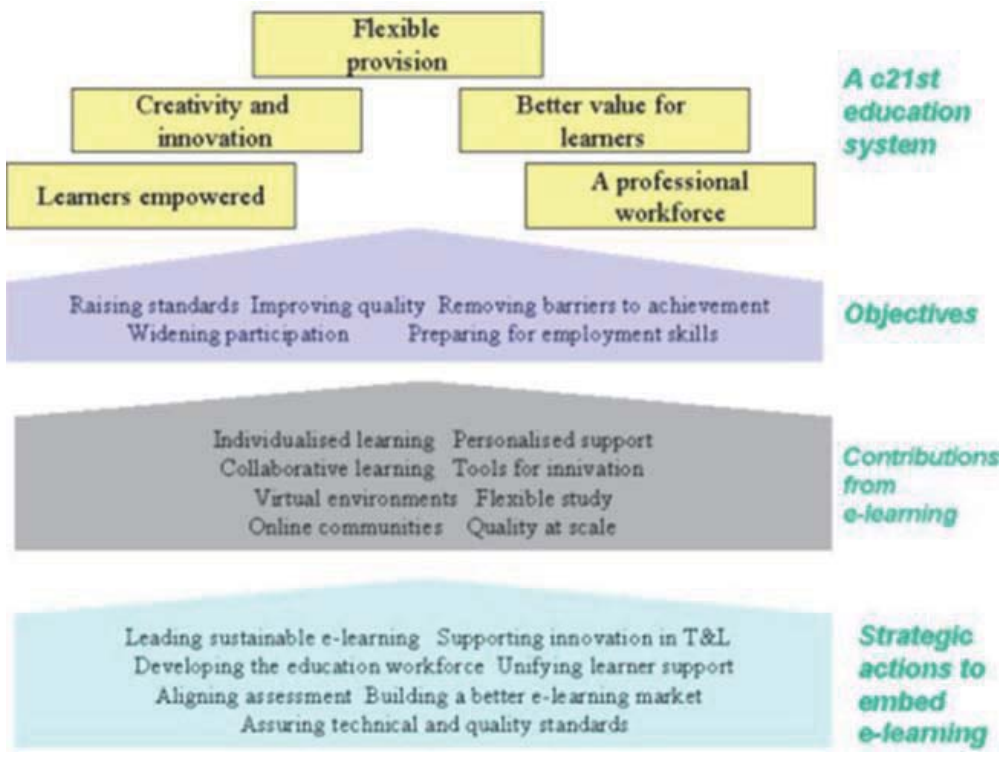

According to Garrison and Anderson, (2003) a policy document for DE needs to be systemic to cover the following: A vision that understands and defines the background, core values and strategic goals attainable through institutional support should be put in place. Identifying challenges, needs, risks, best practices and creation of communities of practice as well as description of educational principles and outcomes should be followed. Leadership should be about implementation initiatives and strategies that link to institutional priorities in a Col.

Design of infrastructure of multimedia spaces, administrative processes, information structures that include institutional connectivity, a knowledge management system, provide quality digital content. Support services that provide professional development and learner support should be put in place. Budget resourcing for research and development should be made for a learning institution to remain current and innovative. Benchmarking to establish success criteria, assess progress and communicate direction and accomplishments for e-learning remains a priority and that sustain support (Garrison et al, 2003, pp.107-109).

Research has identified a number of aspects of "good learning" or Col constructive learning perspectives. These include the following points as quoted from Smith and Zenios, (2004, p.40).

- Learning is active and each learner must carry out a variety of cognitive operations on new information, in order to make it personally meaningful.

- Learning is individual and every learner builds their own knowledge in an idiosyncratic way, using past experiences and existing knowledge to make sense of new information. All new information is dealt with in different ways by different learners.

- Learning is cumulative. What a learner already knows will play a large part in determining what sense they can make of new information.

- Learning is self-regulated, characterized by both (a) the learner's consciousness of their own learning activity and (b) the learner's ability to make a start based on this reflection.

- Learning is goal-oriented with clear, explicit goals in place to make learning effective and understood by all learners.

- Learning is situated as it depends heavily on the social and physical contexts (people, resources and tools) in which learning activity takes place.

- "Learning can be learned".

\section{Conclusion}

In conclusion Col framework represents the most succinct descriptive model for understanding higher education in online learning. By practicing Col programme facilitators are able to make use of varying methods of teaching and learning to 
equip adult educators with ways to deal with the unique diversity of adult learners. More research to contribute to and improve the literature on self-regulated and self -efficacy concepts is needed. These concepts are the interface between learner motivation and cognition (Shea \& Bidjerano, 2010 p, 1724). Other factors to be further explored are: the way learning is affected by immediate environment elements like sound, light, climate and design of learning places. Learner's own emotions including what motivates them to persist in learning take responsibility and their flexibility need more research. Physical needs such as food, strength, mobility are other factors that impede collaborative learning. Sociological factors about how to build relationship with peers and optimise on the community activities need further study. COI encourages understanding of modalities of DE using technology and it also reveals factors that enhance the three presences in a learning environment. Learning outcomes are a product of well thought out stimulating learning environment.

DE is a rapidly growing market and institutions must competitively offer students timely and cost effective Col presences or risk losing them. Strategies for eLearning in DE must offer an education system that is flexible, providing learning opportunities to a diverse range of learners by balancing the three presences described in Col. Online training courseware, simulations, knowledge management tools and access to informational databases are the key support tools for effective Col learning. Creating communities of inquiry that are convivial and collegial would ensure unprecedented learning spaces. The changing characteristics of students in HEls over time require flexible provision of social, cognitive and teaching presences to meet their diverse range of interests. Col is likely to create a situation where student are well supported and skilled graduates capable of problem solving, creative thinking and enhanced capacity to make wise choices about their own learning.

\section{References}

Anderson, T. \& Dron, J., (2011). Three generations of distance education pedagogy. International Review of Research in Online and Distance Learning (IRRODL), 12(3), 80-97. Retrieved from http://www.irrodl.org/index.php/irrodl/article/view/890

Anderson, T. (2003). Getting the mix right again: An updated and theoretical rationale for interaction. International Review of Research in Open and Distance Learning, 4(2). Retrieved from http://www.irrodl.org/index.php/irrodl/article/view/149/230

Berge, Z.L. \& Huang Y.P., (2004). A model for sustainable student retention: A holistic perspective on the student dropout problem with special attention to e-Learning. Retrieved from http://citeseerx.ist.psu.edu/viewdoc/summary?doi=10.1.1.129.1495

Braimoh, D. (2010) Revisiting lifelong learning for quality improvement in ODL institutions in Africa in Africa Education Review 7 (2):229243 UNISA/ Routledge

Brown, S. (2002). Consultation document. In Adelsberger, H.H., Collis, B. \& Pawlowski, J.M. (Eds.) In Handbook on Information Technologies for Education and Training. Berlin: Springer.

Department of Education (2004) Invitation t learn to read and write. National Department of Education. Pretoria. SANLI

Dewey, J. (1959). My pedagogic creed. In Dewey, J. (Ed.), Dewey on education (pp. 19-32). New York: Teachers College, Columbia University

Garrison, D. R., Anderson, T., \& Archer, W. (2000). Critical inquiry in a text-based environment: Computer conferencing in higher education. The Internet and Higher Education, 2(2-3), 87-105. Retrieved from: http://communitiesofinquiry.com/sites/community ofinquiry.com/files/Critical_Inquiry_model.pdf

Garrison, D. R., Anderson, T., \& Archer, W. (2000). Critical inquiry in a text-based environment: Computer conferencing in higher education. The Internet and Higher Education, 2(2-3), 87-105. Retrieved from: http://communitiesofinquiry.com/sites/community finquiry.com/files/Critical_Inquiry_model.pdf

Garrison, D.R. \& Anderson, T., (2003) E-Learning in 21 st century: A framework for research and practice. Retrieved from http:// books.google.co.za.

Garrison, D.R. \& Arbaugh, J.B. (2007). Researching the community of inquiry framework: Review, issues, and future directions/ Internet and Higher Education 10, pp. 157-172.

Garrison, D.R. \& Arbaugh, J.B. (2007). Researching the community of inquiry framework: Review, issues, and future directions. In Internet and Higher Education 10, pp. 157-172. Garrison, D.R. \& Anderson, T., (2003) E-Learning in 21st century: A framework for research and practice. Retrieved from http:// books.google.co.za.

Mishra, P., and Koehler, M. J. (2006). Technological pedagogical content knowledge: A framework for teacher knowledge. Teacher's College Record, 108(6), 1017-1054

Morgan, T. (2011). Negotiating teaching presence: Implications for online teaching, course design, and the Community of Inquiry Framework. CIDER Session. Athabasca University. Available from http://cider.athabascau.ca/CIDERSessions/sessionarchive/

Morgan, T. (2011). Negotiating teaching presence: Implications for on-line teaching, course design, and the Community of Inquiry Framework. CIDER Session. Athabasca University. Retrieved from http://cider.athabascau.ca/CIDERSessions/sessionarchive/

Shea, P. and Bidjerano, T. (2008). Community of enquiry a theoretical framework to foster epistemic engagement and cognitive presence in online education. In Elservier. New York Albany, USA

Smith, C. \& Zenos, P. (2004).Implementing an institutional e-learning centre: Guiding notes and patterns. Retrieved from 
http://www2.tisip.no/E-LEN/

Swan, K. \& Shih, L. F. (2005). On the nature and development of social presence in online course discussions. Journal of Asynchronous Learning Networks, 9, 115-136.

Swan, K. (2010) Teaching and Learning in post- industrial distance education. In M.F Cleveland-Innes \& Garrison D.R. (Eds.). An Introduction to distance education: Understanding teaching and learning in a new era. pp. 108-134). New York \& London, Routledge.

Swan, K., Garrison, D. R., \& Richardson, J. (2009). A constructivist approach to online learning: The community of inquiry framework. In C. R. Payne (Ed.), Information technology and constructivism in higher education: Progressive learning frameworks (pp. 43-57). Hershey, PA: IGI Global.

Swan, K., Garrison, D. R., \& Richardson, J. (2009). A constructivist approach to online learning: The community of inquiry framework. In C. R. Payne (Ed.), Information technology and constructivism in higher education: Progressive learning frameworks (pp. 43-57). Hershey, PA: IGI Global.

UNESCO. 2004. Higher education in a globalized society. UNESCO Education position paper. Paris, UNESCO. 